\title{
Coping styles and aggressiveness in adolescents
}

\section{Style radzenia sobie ze stresem w kontekście agresywności przejawianej przez adolescentów}

\author{
Ewa Łodygowska ${ }^{\boxplus}$, Natalia Hendzelewska², Martyna Tyl² \\ ${ }^{1}$ Uniwersytet Szczeciński, Zakład Psychologii Klinicznej i Psychoprofilaktyki, ul. Krakowska 69, 71-017 Szczecin \\ University of Szczecin, Institute of Psychology, Department of Clinical Psychology and Psychoprophylaxis \\ ${ }^{2}$ Absolwentka Uniwersytetu Szczecińskiego, Instytutu Psychologii na Wydziale Humanistycznym, ul. Krakowska 69, 71-017 Szczecin \\ A graduate of the University of Szczecin, Institute of Psychology at the Faculty of Humanities \\ $\triangle$ ewalodygowska@gmail.com
}

\begin{abstract}
Introduction: Aggressiveness and aggression are important factors contributing to the functioning of young people and their adaptation to the environment. Despite numerous studies on aggression, there are actually no studies on methods of coping with stress among aggressive adolescents. Therefore, the aim of the presented research was to verify whether adolescents with different levels of aggressiveness/aggression reveal different tendencies in the use of styles of coping with stress. Materials and methods: We studied 135 adolescents (aged 16-18), using: 1) the Psychological Inventory of Aggression Syndrome (IPSA) by Gas - enabling identification of three main dimensions of aggression: $\mathrm{S}$ - self-aggression, $\mathrm{U}$ - internal aggression, and Z - external aggression; and 2) the Coping Inventory for Stressful Situations (CISS) by Endler and Parker, in the Polish adaptation by Strelau et al.
\end{abstract}

Results: Based on their level of aggression, the participants were divided into three groups. Compared to their more aggressive peers, in stressful situations, adolescents scoring low on $\mathrm{S}, \mathrm{U}$, and $\mathrm{Z}$ significantly more frequently use task-oriented and significantly less frequently use emotion- and avoidance-oriented coping styles. There is a link between the level of aggressiveness/aggression and the tendency to prefer emotion-focused coping and avoidance-oriented coping in the form of distraction, described as a tendency to engage in substitute activities. Conclusions: Elevated aggressiveness/aggression significantly limits the individual's ability to use constructive methods of coping with stress.

Keywords: aggression; aggressiveness; styles of coping with stress; adolescents.

\begin{abstract}
ABSTRAKT
Wstęp: Agresywność i agresja mogą determinować funkcjonowanie człowieka oraz wpływać na jego przystosowanie się do otoczenia. Mimo licznych badań dotyczących agresji niewiele jest doniesień na temat tego, jak agresywni adolescenci funkcjonują w sytuacjach stresowych. Celem zaprezentowanych badań było zweryfikowanie, czy adolescenci charakteryzujący się różnym poziomem agresywności/agresji ujawniają odmienne skłonności w zakresie stosowania stylów radzenia sobie ze stresem. Materiały i metody: Badaniami objęto 135 adolescentów w wieku 16-18 lat. Zastosowano: 1) Inwentarz Psychologiczny Syndromu Agresji (IPSA) Gasia, umożliwiający wyodrębnienie 3 głównych wskaźników agresji: S - samoagresji, U - agresji ukrytej i Z agresji skierowanej na zewnątrz; 2) Kwestionariusz Radzenia Sobie w Sytuacjach Stresowych (CISS) Endlera i Parkera w polskiej adaptacji Strelaua i wsp.
\end{abstract}

Wyniki: W badaniu wyodrębniono 3 grupy adolescentów o różnym natężeniu poszczególnych wskaźników agresji. W sytuacjach stresowych adolescenci o najmniejszym nasileniu S, U, Z w porównaniu do bardziej agresywnych rówieśników -istotnie częściej wykorzystują styl skoncentrowany na zadaniu, zaś rzadziej styl skoncentrowany na emocjach i unikaniu. Wraz we wzrostem agresywności/agresji znacząco nasila się tendencja do wybierania stylu skoncentrowanego na emocjach oraz stylu skoncentrowanego na unikaniu, w tym jego formy, jaką jest angażowanie się w czynności zastępcze.

Wnioski: Większe nasilenie agresywności/agresji znacząco obniża zdolności jednostki do aktywizowania konstruktywnych sposobów radzenia sobie ze stresem.

Słowa kluczowe: agresja; agresywność; style radzenia sobie ze stresem; adolescenci.

\section{INTRODUCTION}

Aggressive behaviors among adolescents constitute a significant social problem, disrupting development and adaptation and potentially contributing to the escalation of violence among youth $[1,2,3]$. Such behaviors are conditioned by biological, psychological, and environmental factors $[4,5,6,7]$; they can evolve throughout the entire lifespan and be subject to reinforcement [1].
Aggression may also determine human functioning in difficult and stressful situations $[1,8]$ - an aggressive person relatively quickly discovers that aggression provides not only a means of regulating emotions, but also helps satisfy one's needs and quickly achieve goals. If aggressive behaviors result in numerous gratifications, there is a risk that they might become part of one's permanent behavioral repertoire, functioning as a tool to both solve specific problems and reduce 
tension. This, in turn, may reinforce aggressive forms of behavior and reduce those considered more effortful (because they require control over emotions or offer delayed gratification).

As the subject of research inquiries is the association between aggressiveness/aggression of adolescents and their preferred styles of coping with stress, it is worthwhile to present the definitions of both these concepts.

\section{Aggression}

Despite abundant research on the subject, the literature still lacks a clear definition of aggression [9]. In his classic approach, Buss treats aggression as a response that delivers harmful stimuli to another organism [10]. Baron and Richardson complete this definition, highlighting the intentional nature of the perpetrator's actions, as well as the victim's motivation to avoid negative treatment [11]. Currently, most researchers agree that aggression can be defined as (physical or verbal) actions that are intended to inflict (physical or psychological) damage, pain, or loss $[11,12,13]$, though disputes persist over the intentionality of these behaviors and different types of aggression $[12,14]$. The literature also suggests a distinction between "aggression", which is manifested through behavioral acts, and "aggressiveness", understood as an internal disposition towards engaging in aggressive behaviors. Although there is no consensus regarding whether aggressiveness is a biologically conditioned personality trait or one shaped in the course of human development based on individual experience, most researchers describe it as a tendency to respond with frequent and inappropriate aggressive behaviors $[10,13]$, accompanied by hostility towards the environment and difficulties in controlling impulsive reactions. Thus, behavioral displays of aggression are a consequence of experienced aggressiveness.

An attempt to organize and combine both these phenomena was made by Gaś (1980), who described the so-called psychological syndrome of aggression, ie. a set of experiences, attitudes and behaviors whose aim or effect is to cause harm (directly or indirectly) to another person or to oneself. This aggression syndrome includes conscious and subconscious (intentional or unintentional) aggressive tendencies directed outwards or inwards, which are either manifested in action or only experienced internally [15]. Within the aggression syndrome, Gaś distinguishes three main factors, consisting of different types of aggression: 1) the S index - referring to the level of self-directed aggression (both in the form of emotional selfaggression, expressed, i.a., through self-depreciation or selfresentment; and physical self-aggression, manifested through self-injury, self-mutilation, or suicide attempts); 2) the U index related to the so-called hidden (or concealed) aggression, which results from experienced hostility towards the environment and subconscious aggressive tendencies; 3) the Z index - associated with aggression directed outwards, manifested in the form of verbal, physical, indirect, or displaced aggression. The model proposed by Gaś takes into account the complexity of the phenomenon, including not only its externally manifested behavioral aspects, but also the associated internal psychological processes associated.

\section{Coping styles}

The second element of the presented analyses are coping styles, i.e. behavioral and psychological patterns typically adopted by an individual in stressful situations [16].

In this paper, coping styles have been defined based on the concept of Endler and Parker, described in a considerable body of psychological literature $[17,18]$. According to this approach, there are three basic styles of coping with stress - focused either on solving a given problem, on concomitant emotions, or on avoiding confrontation with a difficult situation. And so: the task-oriented style (SSZ) is typical of people who, in stressful situations, strive to actively solve the problem, e.g. through its cognitive transformation or attempts to change the situation. The emotion-oriented style (SSE) involves focusing on one's own emotional experiences and feelings such as tension, guilt, or helplessness. In turn, the avoidance-oriented style (SSU) is identified in people who try to excessively distance themselves from an uncomfortable or stressful situation, mainly through two forms of activity: 1) distraction (SSU-ACZ) - e.g. watching television, sleeping, overeating, shopping, or 2) social diversion (SSU-PKT). Task-oriented coping is construed as active and constructive, while the other two forms are believed to reflect passivity towards the stressful situation $[17,18]$.

Studies to date, conducted among mainly adult populations, have demonstrated significant correlations between aggressiveness/aggression and coping preferences [19]. Findings suggest that people with high levels of aggression (e.g. prisoners, aggressive servicemen) differ from non-aggressive individuals in terms of their coping styles [19]. Reports on the functioning of young people in terms of both these factors remain scarce.

Therefore, the aim of the present research was to verify whether adolescents characterized by different levels of aggressiveness/aggression manifest different tendencies in their use of stress-coping styles. Due to the fact that aggression can largely define human functioning in its various aspects $[1,3$, 8], the research hypothesis has been put forward that young people with different levels of aggressiveness/aggression will differ in terms of their coping preferences.

\section{MATERIALS AND METHODS}

135 randomly selected adolescents aged $16-18$ years participated in the research. The study was carried out in schools in the West Pomeranian Voivodeship, in the period from March to May 2018. In the case of minors, written consent of a parent or legal guardian was obtained. Participation was voluntary and anonymous.

The following tools were used in the research:

1) a self-designed survey, used to collect basic demographic data (gender, age, place of residence, family structure);

2) the Psychological Inventory of Aggression Syndrome (IPSA) by Gaś, designed to measure various dimensions of aggressiveness/aggression. The inventory identifies three main aggression indicators ( $\mathrm{S}, \mathrm{U}, \mathrm{Z}$ ), described above. This 83-item index is characterized by good reliability (stability index of 
.91-.94) and diagnostic validity [15]. Although the norms are meant for persons over 20 years of age, the author also recommends the use of the inventory in adolescents [15]; studies including persons over the age of 17 were conducted by Poklek [13] and Wrzesińska, Grzyb and Kocur [20];

3) the Coping Inventory for Stressful Situations (CISS) by Endler and Parker, in the Polish adaptation by Strelau et al. [19] This tool consists of 48 statements describing behaviors that people tend to adopt in various stressful situations to determine their preferred coping styles: 1) SSZ; 2) SSE; 3) SSU - and its two forms: ACZ and PKT (as described above). The tool is characterized by high reliability (Cronbach's $\alpha=0.73-0.86$ ), satisfactory absolute stability $(0.73-0.80)$ and validity $[19,21]$.

The applied statistical measures included: k-means cluster analysis, Fisher test, Wilcoxon signed-rank test for dependent samples, Kruskal-Wallis test for independent samples, and Dunn's multiple comparison test with Bonferroni correction [22].

\section{RESULTS}

\section{Description of the study group}

The sample comprised a total of 135 adolescents, $46 \%$ boys $(n=62)$ and $54 \%$ girls $(n=73)$, aged $16-18$ years $(M=17.9)$. In the group of respondents $22 \%(\mathrm{n}=30)$ were residents of villages $65 \%(n=88)$ came from cities of $<100,000$ residents, and $13 \%(n=17)$ lived in cities of $>100,000$ residents. Among respondents $71 \%(n=96)$ were brought up in complete families, $16 \%(n=21)$ in incomplete families, and $13 \%(n=18)$ in reconstructed families.

\section{Aggressiveness level}

The adolescents' levels of aggression were analyzed based on the three indicators (S, U, Z). The applied k-means cluster analysis allowed us to distinguish three groups with different severity of the psychological aggression syndrome (Fig. 1).

Group I was characterized by the lowest, and group III the highest severity of self-directed, hidden, and outwarddirected aggression. The F-test confirmed that the groups differed significantly in terms of the $S$ index $(F(2 ; 132)=37.89$, $\mathrm{p}<0.001)$, the $U$ index $(F(2 ; 132)=153.95, \mathrm{p}<0.001)$, and the $\mathrm{Z}$ index $(F(2 ; 132)=356.13 ; \mathrm{p}<0.001)$.

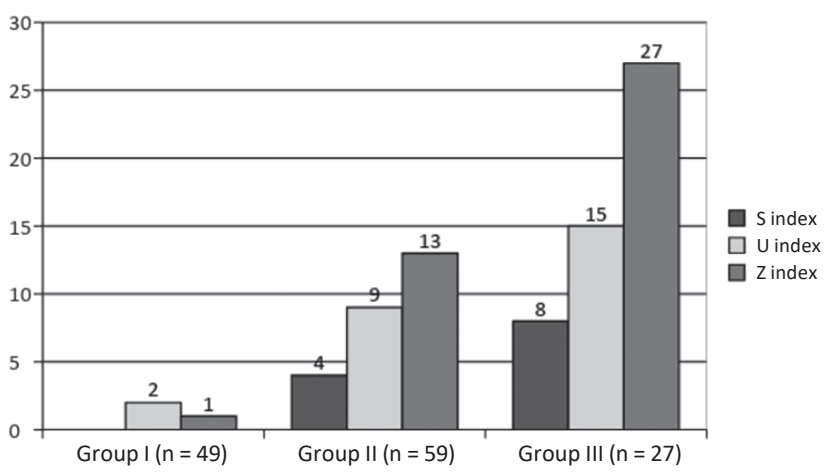

FIGURE 1. Severity of aggressiveness/aggression in the sample (Y axis: $S$ index, U index, Z index; X axis: Group I, Group II, Group III)

\section{Aggressiveness and coping - intra-group comparisons}

In order to verify whether differences in preference toward particular coping styles were significant, the levels of SSZ, SSE, and SSU were compared in each of the groups separately (Fig. 2).

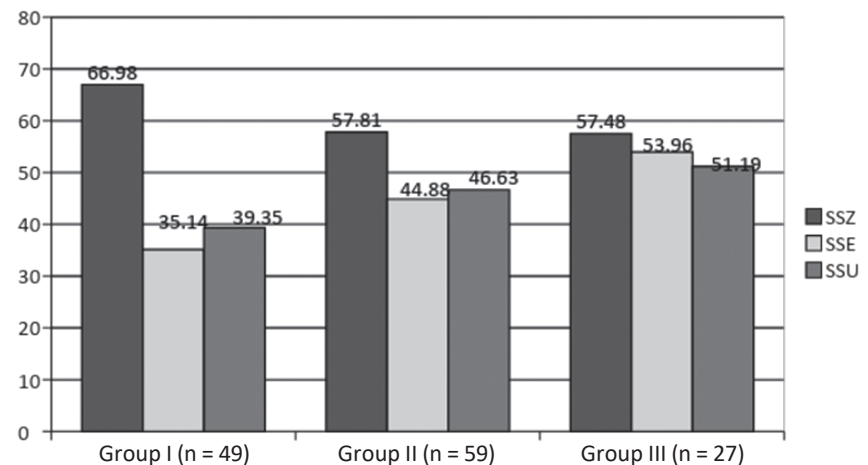

FIGURE 2. Coping preferences in each of the subsamples (X axis: Group I, Group II, Group III)

The Wilcoxon signed-rank test for dependent samples showed a preference toward SSZ in group I, where task-oriented coping was used significantly more frequently than either SSE $(\mathrm{z}=6.25, \mathrm{p}<0.001)$ or SSU $(\mathrm{z}=6.24, \mathrm{p}<0.001)$. The least likely coping choice in group I turned out to be SSE, the frequency of which differed from both SSZ and SSU $(\mathrm{z}=-5.58, \mathrm{p}<0.001)$. The task-oriented style was also the most dominant coping style in group II, and was adopted significantly more often than either SSE $(\mathrm{z}=5.46, \mathrm{p}<0.001)$ or SSU $(\mathrm{z}=3.57, \mathrm{p}<0.001)$, though the difference between the use of SSE and SSU was also statistically significant $(\mathrm{z}=2.1, \mathrm{p}=0.036)$. Interestingly, in group III, characterized by the highest intensity of aggressiveness/aggression, we did not identify any particular coping preferences $(z=n s)$.

\section{Aggressiveness and coping - an inter-group comparison}

In the next stage, the three groups were compared in terms of the frequency of use of particular coping styles (Fig. 3), including the three main styles (SSZ, SSE, SSU) and two forms of SSU: SSU-ACZ and SSU-PKT.

The nonparametric Kruskal-Wallis test for independent samples (Tab. 1) demonstrated statistically significant intergroup differences for the majority of factors.

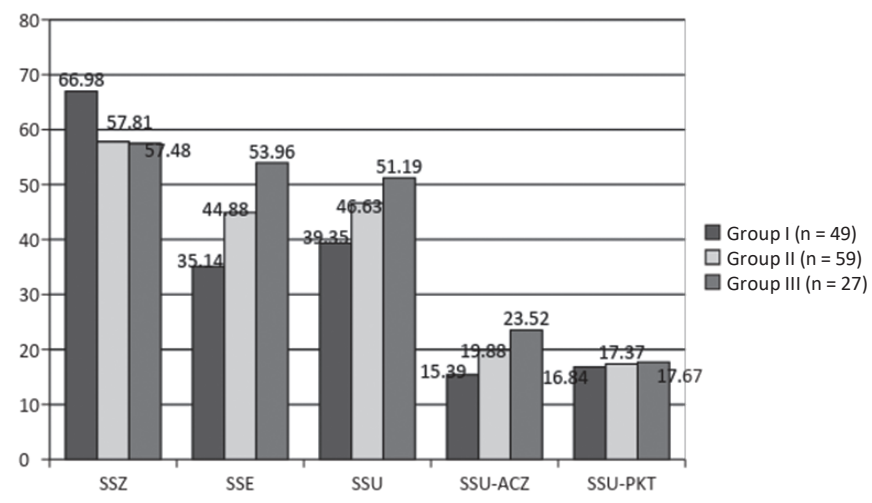

FIGURE 3. Intergroup differences in the frequency of use of particular styles of coping with stress (Y axis: Group I, Group II, Group III) 
The three compared groups differed in terms of the frequency of application of task-, emotion-, and avoidance-oriented coping styles, as well as their level of engagement in distraction. No statistically significant differences were found in the frequency of their use of social diversion as a coping style in stressful situations (Tab. 1).

In order to verify the differences between particular groups, pairwise comparisons with the Dunn test and Bonferroni correction were conducted (Tab. 2).

TABLE 1. Intergroup comparison of the frequency of use of particular coping styles

\begin{tabular}{lccc} 
& \multicolumn{3}{c}{ Kruskal-Wallis test } \\
\cline { 2 - 4 } Coping style & H & df & p \\
\hline SSZ & 26.01 & 2 & $<0.001$ \\
\hline SSE & 64.23 & 2 & $<0.001$ \\
\hline SSU & 34.05 & 2 & $<0.001$ \\
\hline SSU-ACZ & 34.05 & 2 & $<0.001$ \\
\hline SSU-PKT & 3.68 & 2 & 0.159
\end{tabular}

TABLE 2. Intergroup differences - Dunn's pairwise comparisons

\begin{tabular}{lccc}
\multirow{2}{*}{ Coping style } & \multicolumn{3}{c}{ Compared groups } \\
\cline { 2 - 4 } & I-II & I-III & II-III \\
\hline SSZ & $35.83^{* * *}$ & $34.71^{* * *}$ & -1.118 \\
\hline SSE & $-39.63^{* * *}$ & $-72.13^{* * *}$ & $-32.51^{* *}$ \\
\hline SSU & $-34.79^{* * *}$ & $-48.77^{* * *}$ & -13.98 \\
\hline SSU-ACZ & $-28.98^{* * *}$ & $-52.03^{* * *}$ & $-23.06^{*}$ \\
\hline
\end{tabular}

${ }^{*} \mathrm{p}<0.05 ;{ }^{* *} \mathrm{p}<0.01 ;{ }^{* * *} \mathrm{p}<0.001$

The analysis revealed that most of the identified intergroup differences were statistically significant (Tab. 2). The least aggressive adolescents (group I) were found to prefer task-oriented coping (SSZ) significantly more often than their peers with a moderate (group II) or high severity of aggressive behaviors (group III). At the same time, there were no statistically significant differences between groups II and III in the frequency of using SSZ.

Moreover, along with an increase in aggressiveness/aggression, there was a significant rise in the tendency to prefer emotion-oriented coping (SSE) - i.e. there are significant intergroup differences (Tab. 2) suggesting that adolescents with the highest intensity of self-directed, hidden, and outwards-directed aggression (group III) may resort to using this coping style more frequently than their less aggressive peers. Accordingly, the least aggressive teens tended to use this style the least frequently.

In the case of avoidance-oriented coping - group I is definitely the most remarkable. Namely, according to our findings, the least aggressive adolescents are also the least likely to adopt this style of coping with stress and thus differ significantly from their peers in the other two groups (between whom there are no statistically significant differences in the frequency of using this coping style).
There are some interesting observations concerning distraction (SSU-ACZ). First of all, the least aggressive adolescents seem to use this coping strategy the least frequently, and the differences between them and their peers in the other two groups are statistically significant (Tab. 2). Secondly, teenagers from group III, with the highest severity of aggressive behaviors, tend to choose this method of tackling stressful situations more frequently than any other available coping strategy, which significantly distinguishes them from the other two groups. This means that as aggressiveness/aggression increases, so does adolescents' tendency to cope with a difficult situation by engaging in distracting tasks and activities.

In the case of the other SSU dimension, social diversion (SSU-PKT), no post-hoc comparisons were made, because the Kruskal-Wallis test did not show significant differences between the three groups.

\section{DISCUSSION}

The research results have provided grounds for some significant observations. First of all, they showed that aggressiveness and aggression among adolescents are not limited to behavioral displays of violence (either towards themselves or others), but are also reflected in other areas of functioning, including the ways teens cope with stress.

Adolescents who demonstrate the lowest severity of selfdirected, hidden, and outward-directed aggression, are found to act most effectively in stressful situations. Thanks to their ability to focus on the given task, they are able to solve problems and avoid improper allocation of their psychological resources, such as focusing on experienced emotions (SSE) or seeking distraction through substitute activities. As a consequence, they may be able to better adapt to reality, which agrees with other reports $[8,19,23]$.

The findings, however, do not demonstrate significant differences between adolescents of different levels of aggressiveness/aggression in terms of the other form of avoidance-oriented coping, social diversion. Nevertheless, it is worth noting that the applied measurement tool (CISS) does not specify the purpose of pursued social contacts. Therefore, it is debatable whether group I adolescents apply this strategy to seek informational or emotional support necessary to rationally deal with the problem, or whether their actions should be perceived as mere avoidance thereof. Their preference for task-oriented coping seems to point to the former, but the specificity of the applied tool leaves this matter unresolved and thus an area in need of further research.

The moderate aggressiveness/aggression group (II) initially appears quite similar to group I in their coping preferences. However, subsequent analyses suggest that their frequency of using task-oriented coping is significantly lower than that of their group I peers (but similar to group III), while the frequency of using both emotion-oriented and avoidance-oriented coping remains significantly higher. Such diversity of results indicates that with an increase in aggressiveness/aggression, 
teenagers' ability to use constructive coping drops, and more maladaptive strategies are favored, which also agrees with previous studies [19, 24, 25].

Also noteworthy is the group exhibiting the highest levels of self-directed, hidden, and outward-directed aggression (III). Firstly, in this group unlike in the other two, we failed to determine a dominant coping style - i.e. there was no difference in the frequency of using SSZ, SSU, and SSE. This means that the most aggressive teens tend to exhibit a similar preference for adaptive (SSZ) and maladaptive (SSE, SSU) coping styles. At the same time, they clearly differ from their least aggressive peers, reporting the least frequent preference for SSZ and more frequent manifestations of both SSE and SSU, indicating that compared to less aggressive adolescents they have a significantly less developed propensity for constructive coping with stress.

Interestingly, their heightened use of emotion-oriented coping clearly distinguishes this group from the other two. The results may thus indicate the existence of mechanisms hindering adaptation in the most aggressive individuals. Aggressiveness and aggression, concomitant to emotionoriented coping, may limit one's ability to rationally solve current problems, which results in further consequences especially if the stressful situation is associated with important life events. As a result, unresolved issues can contribute to a build-up of negative emotions and tensions, which may find their outlet in the form of aggressive behaviors. This, in turn, leads to further problems (e.g. in the form of potential social consequences) and more stressful situations, forcing the individual to take actions aimed at tackling the experienced stress. If a person lacks positive experience and skills necessary to apply adaptive coping methods, he can once again resort to non-rational strategies, thus falling into a vicious circle of non-constructive behaviors and unresolved problems. In light of these considerations, research results appear quite reasonable - indicating a limited ability to cope with stress among the most aggressive people.

To summarize, aggression and aggressiveness in adolescents constitute a significant problem, reflected not only in the form of presently manifested behaviors, but having serious longterm implications. The relationship between aggressiveness/ aggression and non-constructive coping styles, highlighted in this research, may be an important premise for preventive and therapeutic actions aimed at young people, especially impulsive or aggressive ones.

The presented research has certain limitations. These include a small sample size and the use of self-reporting tools, which warrant certain caution in the generalization of results. In addition, due to the limited scope of the research, some otherwise important factors (e.g. temperament, use of psychoactive substances, general medical condition) that may be related to the analyzed variables have been neglected [1]. Therefore, it is beyond any doubt that this area of research warrants expansion, especially among adolescent populations, i.e. people at the threshold of independent decisions and life choices.

\section{CONCLUSIONS}

1. Adolescents with the lowest severity of self-directed, hidden, and outward-directed aggression tend to choose taskoriented coping strategies most frequently, whilst being least likely to rely on emotion-oriented coping, unlike youth with the highest level of aggressiveness/aggression, in whom no particular coping style prevails.

2. In stressful situations, teens with the lowest aggressiveness/aggression levels use constructive coping significantly more often than their more aggressive peers.

3. Along with an increase in aggressiveness/aggression, the preference toward emotion-oriented coping rises significantly as well. Hence, adolescents with the highest levels of self-directed, hidden, and outward-directed aggression resort to using this particular style of coping more frequently than their less aggressive peers.

4. The severity of aggressiveness/aggression is significantly associated with the tendency to engage in distraction as a way of coping with stress. The most aggressive adolescents choose this form of coping significantly more frequently, while for their least aggressive peers, this seems the least appealing coping style.

\section{REFERENCES}

1. Pufal-Struzik I. Agresywność młodzieży. Źródła, mechanizmy, oblicza. Kielce: Wyd. UJK; 2014

2. Obuchowska I. Agresja dzieci w perspektywie rozwojowej. In: Binczycka-Anholcer M, editor. Agresja i przemoc a zdrowie psychiczne. WarszawaPoznań: PTHP; 2001.

3. Urban B. Agresja młodzieży i odrzucenie rówieśnicze. Warszawa: PWN; 2015.

4. Huesmann RL. Agresja z pokolenia na pokolenie. In: Zagrodzka J, Kowaleczko-Szumowska M, editors. Psychospołeczne i neurobiologiczne aspekty agresji. Warszawa: Wyd. Instytutu Psychologii PAN; 2005.

5. Krahe B. Psychologiczne uwarunkowania agresji. In: Zagrodzka J, Kowaleczko-Szumowska M, editors. Psychospołeczne i neurobiologiczne aspekty agresji. Warszawa: Wyd. Instytutu Psychologii PAN; 2005.

6. Lopez EE, Perez SM, Ochoa M, Ruiz DM. Adolescent aggression: effects of gender and family and school environments. J Adolesc 2008;31:433-50.

7. Łodygowska E, Tyl M. Psychologiczny syndrom agresji adolescentów w kontekście funkcjonowania rodziny i rodziców. Psychologia Rozwojowa 2018;23:23-37.

8. Niewiadomska I, Markiewicz R. Nasilenie psychologicznego syndromu agresji jako czynnik ryzyka czynów karalnych popełnianych przez nieletnich. In: Kuć M, Niewiadomska I, editors. Kara kryminalna. Analiza psychologiczno-prawna. Lublin: Towarzystwo Naukowe KUL; 2004.

9. Rode D. Psychologiczne uwarunkowania przemocy w rodzinie. Charakterystyka sprawców. Katowice: Wyd. UŚ; 2010.

10. Buss AH. The psychology of aggression. New York: Wiley and Sons; 1961.

11. Baron RA, Richardson DR. Human aggression. New York: Plenum; 1994.

12. Frączek A. 0 naturze i formowaniu się psychologicznej regulacji agresji interpersonalnej. In: Kurcz I, Kądzielowa D, editors. Psychologia czynności. Warszawa: Wyd. Nauk. Scholar; 2002.

13. Poklek R. Inwentarz Psychologiczny Syndromu Agresji Z.B. Gasia w diagnostyce penitencjarnej - normalizacja narzędzia. Przegląd Więziennictwa Polskiego 2008;61:69-101.

14. Fronczak A. Agresja dzieci w świetle teorii społeczno-poznawczej. Rehabilitacja Polska 2017;13:73-85.

15. Gaś ZB. Inwentarz Psychologiczny Syndromu Agresji. Przegląd Psychologiczny 1980;23(1):143-54. 
16. Heszen-Niejodek I. Teoria stresu psychologicznego i radzenia sobie: główne kontrowersje. In: Strelau J, editor. Psychologia. Podręcznik akademicki. Tom 3. Gdańsk: GWP; 2006.

17. Endler NS, Parker JDA. Assessment of multidimensional doping: Task, emotion and avoidance strategies. Psychol Assess 1994;6:50-60.

18. Endler NS, Parker JDA. Coping inventory for stressful situations: CISS manual. 2nd ed. New York: Multi-Health Systems; 1999.

19. Strelau J, Jaworowska A, Wrześniewski K, Szczepaniak P. Kwestionariusz Radzenia Sobie w Sytuacjach Stresowych - CISS. Warszawa: Pracownia Testów Psychologicznych; 2007.

20. Wrzesińska MA, Grzyb J, Kocur J. Poziom agresywności i specyficznych zachowań agresywnych u chorych z zaburzeniami czynnościowymi układu pokarmowego. Post Psychiatr Neurol 2008;17(1):35-8.
21. Jabłońska A. Trafność teoretyczna Kwestionariusza radzenia sobie w sytuacjach stresowych CISS ze szczególnym uwzględnieniem trafności teoretycznej skali stylu skoncentrowanego na unikaniu. Testy Psychologiczne w Praktyce i Badaniach 2015;1:31-51.

22. Ferguson GA, Takane Y. Analiza statystyczna w psychologii i pedagogice. Warszawa: PWN; 2003.

23. Chęć M. Style funkcjonowania społeczno-emocjonalnego młodzieży identyfikującej się z subkulturą Emo [dissertation]. Gdańsk: Uniwersytet Gdański; 2010.

24. Whitman CN, Gottdiener WH. Implicit coping styles as a predictor of aggression. J Aggression Maltreatment Trauma 2015;24(7):809-24.

25. Naquin MR, Gilbert GG. College students' smoking behavior, perceived stress, and coping styles. J Drug Educ 1996;26(4):367-76. 